\title{
REFERENCES
}

Cowan, S. T., AND STEEL, K. J. . . . 1965. Manual for the identification of medical bacteria, Cambridge, p. 58.

Cruickshank, R., And Sharman, A. 1934a. J. Obstet. Gynaec. Br. Emp., 41, 190.

INGRAM, G. ." . . . . . . . . . . . . 1962. Methods of organic elemental micro-

KIENLIN, H. .

de Man, J. C., Rogosa, M., ANd Sharpe, 1960. J. Appl. Bact., 23, 130.

M. ELISABETH

Niven, C. F., JR, Smiley, K. L., AND 1943. J. Bact., 43, 651.

SHERMAN, J. M.

Roe, J. H., Bailey, J. M., Gray, R. R., 1961. J. Biol. Chem., 236, 1244. AND ROBINSON, J. N.

Rogosa, M., and Sharpe, M. Elisabeth 1960. J. Gen. Microbiol., 23, 197.

SCHRÖDER, R., HiNRICHS, R., AND 1926. Arch. Gynäk., 128, 94.

KESSLER, R.

STEWART-Tull, D. E. S. . . . . . 1964. Amer. J. Obstet. Gynec., 88, 676.

\section{NALIDIXIC ACID (NEGRAM) DISC TECHNIQUE FOR THE RAPID ISOLATION OF FAECAL STREPTOCOCCI FROM MIXED FLORA}

\author{
S. K. Devaraj and K. ZinnemanN \\ Department of Bacteriology, School of Medicine, Leeds
}

FAILURE of treatment of urinary infections due to faecal streptococci in association with other bacteria (Garrod, Shooter and Curwen, 1954) has indicated the need for combined antibiotic therapy in these cases (Eisenberg, Alexander and Flippin, 1953).

The incidence of streptococci in mixed urinary infections appears to vary from 10 per cent. (Sanford et al., 1956) to 22.4 per cent. (Rantz and Kirby, 1943). As could be expected, faecal streptococci were also found with coliform bacilli in gastro-intestinal perforation leading to peritonitis (Rantz and Kirby).

The difficulties of recovering faecal streptococci from a mixed flora have been noticed from time to time. Seidman, Ellis and Hill (1929) observed a lack of correlation between the smear and the culture of urinary sediments. Baker (1931) also noted that only Gramnegative organisms appeared in cultures although both Gram-positive and Gram-negative organisms were seen in smears. The possibility of suppression by the predominant organism has been suggested by Flint (1951) and Giertz and Gullbring (1951). Gould (1951) explained the discrepancy by the more rapid growth of the Gram-negative bacilli in a mixed urinary tract infection.

As streptococci (except occasional strains) are not inhibited by nalidixic acid in vitro, they can be isolated conveniently from the zones of inhibition of the coliform bacilli on primary culture plates.

\section{MATERIALS AND METHOD}

Media. (1) Nutrient agar. (2) MacConkey's agar, both for primary culture and isolation. (3) Five per cent. fresh horse blood agar plates for sensitivity tests.

Urine specimens. Centrifuged deposits of urine were examined by culture, and by wet and by Gram-stained preparations. One loopful of deposit was seeded on nutrient agar and MacConkey's agar, and incubated aerobically at $37^{\circ} \mathrm{C}$. 
Other clinical specimens. A small number of specimens of pus, peritoneal swabs and wound swabs containing a mixed flora as judged by the Gram-stained smears were seeded on blood and chocolate agar plates and incubated aerobically.

Whenever a smear stained by Gram's method indicated a mixed flora of Gram-negative rods and Gram-positive cocci " Negram" filter-paper discs at concentrations of 30 and $100 \mu \mathrm{g}$ per disc were placed on the primary culture plates.

Evaluation of the nalidixic acid resistance of streptococci was recorded in the manner suggested by Truant, Bolin and Mullins (1964), as "very susceptible", " moderately susceptible ", "slightly susceptible" and " resistant".

The non-committal clinical term "faecal streptococci" is used throughout, and denotes the species present in fresh faecal excreta that include all of the Enterococcus group as well as other groups of streptococci. We hope to publish the results of further classification of the isolates later.

TABLE

In-vitro sensitivity to nalidixic acid of 200 strains of faecal streptococci

\begin{tabular}{l|c|c}
\hline \multicolumn{1}{c|}{ Grading } & Pattern of inhibition & Number of strains \\
\hline Resistant & No inhibition around 30 and $100 \mu \mathrm{g}$ discs & 184 (92 per cent.) \\
\hline $\begin{array}{c}\text { Slightly } \\
\text { susceptible }\end{array}$ & $\begin{array}{c}\text { No inhibition around } 30 \mu \mathrm{g} \text { disc, } 1-2 \mathrm{~mm} \\
\text { around } 100 \mu \mathrm{g} \text { disc }\end{array}$ & $13(6.5 \mathrm{per}$ cent.) \\
\hline $\begin{array}{c}\text { Moderately } \\
\text { susceptible }\end{array}$ & $\begin{array}{c}1-2-\mathrm{mm} \text { zone of inhibition around } 30 \mu \mathrm{g} \\
\text { disc, larger zone around } 100 \mu \mathrm{g} \text { disc }\end{array}$ & $1(0 \cdot 5$ per cent.) \\
\hline $\begin{array}{c}\text { Very } \\
\text { susceptible }\end{array}$ & $\begin{array}{c}5-10-\mathrm{mm} \text { zones of inhibition around both } \\
30 \text { and } 100 \mu \mathrm{g} \text { discs }\end{array}$ & 2 (1 per cent.) \\
\hline
\end{tabular}

RESULTS

The majority of faecal streptococci grew freely in the zones of inhibition of the coliform flora. Only 3 out of 200 strains of faecal streptococci ( 1.5 per cent.) were inhibited by the commonly used concentration of $30 \mu \mathrm{g}$ of nalidixic acid per disc (see table). Even at the high concentration of $100 \mu \mathrm{g}$ per disc only 16 strains ( 8 per cent.) were sensitive to nalidixic acid. Thus 98.5 per cent. of faecal streptococci in this series could be isolated from heavy mixed cultures, provided the coliform bacilli were inhibited by $30 \mu \mathrm{g}$ of nalidixic acid.

\section{Discussion}

Our results, which show that over 98 per cent. of faecal streptococcus strains are not inhibited by nalidixic acid are at variance with those of some authors who found a considerably higher proportion of faecal streptococci to be sensitive to nalidixic acid. Thus, Carroll (1963) reported 1 enterococcus strain out of 5 tested to be sensitive to 5, 30 and $60 \mu \mathrm{g}$; and Lishman and Swinney (1963) found 1 out of 13 strains of Streptococcus faecalis strains to be sensitive to $60 \mu \mathrm{g}$.

On the other hand, Beerens and Tahon-Castel (1966) failed to find streptococci in groups $\mathrm{A}, \mathrm{B}, \mathrm{C}, \mathrm{D}, \mathrm{E}$ and $\mathrm{N}$ that were sensitive to $40 \mu \mathrm{g}$ per $\mathrm{ml}$ of nalidixic acid. They used the compound in this concentration for the isolation of streptococci, Diplococcus pneumoniae, Listeria and Erysipelothrix. As the majority of Gram-negative bacilli occurring in urine specimens is inhibited by concentrations of nalidixic acid from 10 to $60 \mu \mathrm{g}$ (Deitz, Bailey 
and Froelich, 1963; Lishman and Swinney), a high percentage of faecal streptococcus strains can be expected to be isolated from mixed urinary infections by the routine use of concentration gradients of nalidixic acid produced by discs. Various methods for selectively growing faecal streptococci were described by Litsky, Mallmann and Fifield (1953) including ox bile, potassium tellurite, sodium azide, methylene blue, ethyl violet, crystal violet and trypan blue, either alone or in combination in liquid and solid media. The nalidixic acid isolation method has been used by us as a routine, and has the advantage, over other selective methods, of simplicity, reliability, low cost and saving of time.

\section{SUMMARY}

Over 98 per cent. of 200 faecal streptococcus strains isolated from mixed flora, mainly in specimens of urine but also in pus, peritoneal and wound swabs were resistant to $30 \mu \mathrm{g}$ of nalidixic acid.

Placing filter paper discs containing $30 \mu \mathrm{g}$ of nalidixic acid on primary plates inoculated with mixed flora is a reliable and simple method of isolating faecal streptococci from specimens containing a large admixture of Gram-negative bacilli.

We wish to thank Dr J. G. Shoesmith, Dr T. H. Williets, Dr A. S. Wotherspoon and Dr J. M. H. Boyce for additional strains given to us during this work.

\section{REFERENCES}

BAKER, W. J. . . . . . . . . 1931. Trans. Chicago Urol. Soc., 1, 171.

Beerens, H., and Tahon-Castel, M. M. 1966. Annls Inst. Pasteur, Paris, 111, 90.

CARroll, G. . . . . . . . . . . 1963. J. Urol., 90, 476.

Deitz, W. H., Bailey, J. H., and Froe- 1963. Antimicrob. Ag. Chemother., p. 583. LICH, E. J.

Eisenberg, G. M., Alexander, J. D., AND 1953. J. Amer. Med. Assoc., 152, 1302.

FlipPIN, H. F.

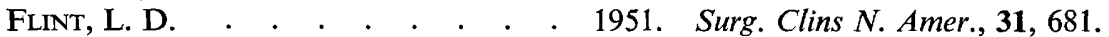

Garrod, L. P., Shooter, R. A., AND 1954. Br. Med. J., 2, 1003.

CuRWen, M. P.

Giertz, G., AND Gullbring, B. . . 1951. Acta chir. scand., 102, 121.

Gound, J. C. . . . . . . . . 1951. Edinb. Med. J., 58, Trans. Med.-Chir. Soc. Edinb., 62.

Lishman, I. V., AND Swinney, J. . . 1963. Br. J. Urol., 35, 116.

Litsky, W., MallmanN, W. L., and 1953. Amer. J. Publ. Hlth, 43, 873. FIFIELD, C. W.

RANTZ, L. A., AND KIRBy, W. M. M. - 1943. Archs Intern. Med., 71, 516.

SANFord, J. P., Favour, C. B., MaO, 1956. Amer. J. Med., 20, 88. F. H., AND HARRISON, J. H.

Seidman, L. R., Ellis, M. G., ANd Hill, 1929. J. Urol., 22, 717. J. $\mathrm{H}$.

Truant, J. P., Bolin, Jean E., and 1964. Antimicrob. Ag. Chemother., 384. Mullins, JEANETTE 